\title{
Evaluation of Green Bean (Phaseolus vulgaris) Varieties in South Gondar Zone, North West Ethiopia
}

\author{
Birhanu Habtie Mulat Getaneh Dejen Bekis \\ Ethiopian Institute of Agricultural Research (EIAR), Fogera Agricultural Research Center, \\ Bahir Dar, P.O.Box 1937, Ethiopia
}

\begin{abstract}
Farmers in Fogera plane used to produce commonly and widely some horticultural crops like onion, garlic, pepper and tomatoes at the same time under rain fed or using irrigated growing conditions. Harvesting made at the same time and farmers faced to get easily accessibility of market opportunity with good prices and they ought to sell their products in low prices. Furthermore, repeated cultivation of similar crops in a plot leads to build up of diseases and insects and loss of productivity and quality products. Introduction of new crops from different family (legume) like improved green bean varieties and testing their adaptability is crucial as an alternative crop to these provinces. The study was carried out at three plots in Fogera (on-station), Dera (Gumara kebele) and Libokemekem (Angote Kebele) districts using irrigated growing conditions in 2018/19. Two green bean varieties namely Platie and BC-4.4 were used in this performance evaluation; they are only available varieties in Ethiopia. Variety platie performed better all locations for marketable green pod yield, fruit length, fruit width, fruit weight and less percentage of unmarketable green pod yield. It has also early maturity nature as compared to BC.44. Hence, platie is prominent as a potential variety and recommended for production in South Gondar Zone especially in Fogera, Dera and Libokemkem distiricts. Therefore, seed multiplication of this variety and demonstration of its production practices to small-scale farmers is vital in these provinces.
\end{abstract}

Keywords: Alternative crop, disease, fertility, legume, Phaseolus vulgaris, rotation

DOI: $10.7176 / \mathrm{JBAH} / 11-13-04$

Publication date:July $31^{\text {st }} 2021$

\section{Introduction}

The green bean was native to the hot region of the Americas, India and China (Wiersinga and Jager, 2007). It is a popular warm-season vegetable crop which is very sensitive to frost and also dislikes hot conditions. It can be successfully cultivated on a wider variety of soil types, ranging from sands to relatively heavy clays (Subbarao and Johansen, 1994).

Green bean has high nutritional value which is a good source of vitamins like vitamin C, A and K, foliate and riboflavin, and minerals like iron, calcium and magnesium, and add dietary fiber to human diet (PCARRDDOST Portal, 2007). It is versatile vegetable that can be eaten raw or cooked, in various dishes. The green bean is also an important plant to add to crop rotation system due to its ability to fix nitrogen in the soil which helps to build nutrients in the soil.

Green bean is one of the newly introduced legume crops in Ethiopia and it is an important crop in the provision of food security and earing foreign currency. Its production was started by large-scale state-owned farms in the early 1970's (Wiersinga and Jager, 2007) and it is also widely produce by many private farms till now in Southern and Central parts of the country. However, Ethiopian farmers in most cases have been limited to grow green bean due to less awareness creation of how to produce the crop and its multi field advantages. Besides, availability of few cultivars with high cost of seed owned by private company is another limited factor for green bean production to far reaching at farmer's level.

Practically farmers in Fogera, Dera and Libokemkem districts used to commonly and widely cultivate few horticultural crops like onion, garlic, pepper and tomatoes under rain fed and irrigated growing conditions. Since they to produce similar crops within the same season/time, supply to market is high during s season forcing growers to sell with very low price, while climbs up at another time when there is there is shortage of supply. Due to repeated cultivation of these few vegetables from season to season and year to year, productivity and quality of harvest is decreasing from time to time. Even in many years, production of major vegetables being abandoned solely due to buildup of diseases and insects. Hence, cultivation of alternative crop like green bean using improved varieties will increase income generation, diversification, rotation to soils, and reduce crop and market failure in these areas.

Hence, efforts goes to introduction of green been cultivar as well as establishing good seed production system into the new growing potential areas like Fogera, Dera and Libokemkem districts. This is very important to expand its production practices at small holder farmers' level. Consequently, this experiment was designed to introduce the new improved green bean varieties for testing their adaptability in province of Fogera, Dera and Libokemkem which are found in North Western Ethiopia. 


\section{Materials and Methods}

The study was carried out at three plots in Fogera (on-station), Libokemekem (Angote kebele) and Dera (Gumara kebele) using irrigated growing conditions in 2018/19. Two green bean varieties namely Plati and BC4.4 were used in the study. These varieties are the only available varieties in Ethiopia which were released from Melkasa Agricultural Research Center (Alemu et.al, 2018). The trial was laid out in randomized complete block design with four replications. Each plot consists seven rows of $2.8 \mathrm{~m}$ length and $3 \mathrm{~m}$ width. A distance of $0.5 \mathrm{~m}$ between plots was used and the distance between ridge and replications were, $0.4 \mathrm{~m}$ and $1 \mathrm{~m}$, respectively. The recommended seed rate of $40 \mathrm{~kg} / \mathrm{ha}$ and fertilizer rate of $120 \mathrm{~kg} / \mathrm{ha}$ NPS and $100 \mathrm{~kg} / \mathrm{ha}$ Urea was used at all testing locations (Negash et.al, 2018). Application of all amounts of NPS was applied during sowing while the required amount of Urea was applied into two, the first half was at the time of sowing and second half was applied after a month from sowing. Irrigation was done within the interval of 7 days for the first three weeks and then applied in the interval of 10 days after three successive weeks. As indicated below, important parameters for data collection were considered for both varieties at three locations.

Traits measured on plot basis: marketable green pod yield, unmarketable green pod yield, days to $50 \%$ emergency and days to $50 \%$ flowering

Traits measured on plant basis: plant height, number of primary and secondary branches, pod length, pod width and average pod weight.

\section{Results and Discussion}

\subsection{Analysis of Variance}

The results of combined analysis of variances of nine traits for two green bean genotypes tested at Fogera, Dera and Libokemkem districts analyzed using randomized complete block design is presented in Table 1. Based on the combined data analysis, significant $(\mathrm{P}<0.05)$ different in marketable green pod yield, plant height, pod length, days to $50 \%$ emergency and days to $50 \%$ flowering were recorded between varieties over the three locations. However, single pod weight, pod width, number of primary and secondary branches showed non-significant variation between two varieties when analyzed over the three locations.

Alike marketable green pod yield and pod width were also significantly $(p<0.05)$ affected by interaction of varieties and locations. On the other hand, the analysis of variance over the three locations indicated that the difference in plant height, single pod weight, pod length, primary and secondary branches, days to $50 \%$ emergency and flowering were revealed non-significant interaction effect between varieties and locations.

Table 1.

\begin{tabular}{|l|c|c|c|c|c|c|}
\hline \multicolumn{1}{|c|}{ Traits } & $\begin{array}{c}\text { Replication with in } \\
\text { location(Df=9) }\end{array}$ & $\begin{array}{c}\text { Locations } \\
(\mathrm{Df}=2)\end{array}$ & $\begin{array}{c}\text { Varieties } \\
(\mathrm{Df}=1)\end{array}$ & $\begin{array}{c}\text { Location x Varieties } \\
(\mathrm{Df}=2)\end{array}$ & $\begin{array}{c}\text { Error } \\
(\mathrm{Df}=9)\end{array}$ & $\begin{array}{c}\text { CV } \\
\text { Marketable Yield(t/ha) }\end{array}$ \\
$26.19^{*}$ & $469.1^{* *}$ & $75.26^{*}$ & $5.902^{* *}$ & 4.30 & 11.6 \\
\hline Plant Height (cm) & $16.83 \mathrm{~ns}$ & $32.71 \mathrm{~ns}$ & $134.9^{* *}$ & $9.645 \mathrm{~ns}$ & 8.03 & 5.44 \\
\hline $\begin{array}{l}\text { Single pod weight } \\
\text { (gm.) }\end{array}$ & $0.404 \mathrm{~ns}$ & $13.81^{* *}$ & $1.870 \mathrm{~ns}$ & $2.715 \mathrm{~ns}$ & 0.65 & 12.5 \\
\hline Pod width (mm) & $3.830 \mathrm{~ns}$ & $7.965 \mathrm{~ns}$ & $4.420 \mathrm{~ns}$ & $14.22^{*}$ & 3.00 & 21.9 \\
\hline Pod length (cm) & $2.099^{* *}$ & $0.708 \mathrm{~ns}$ & $22.04^{* *}$ & $0.108 \mathrm{~ns}$ & 0.31 & 4.30 \\
\hline Primary branches & $0.164 \mathrm{~ns}$ & $0.107 \mathrm{~ns}$ & $2.406 \mathrm{~ns}$ & $1.126 \mathrm{~ns}$ & 0.52 & 14.5 \\
\hline Secondary branches & $0.227 \mathrm{~ns}$ & $56.55^{*}$ & $1.926 \mathrm{~ns}$ & $5.542 \mathrm{~ns}$ & 1.82 & 8.70 \\
\hline $\begin{array}{l}\text { Days to } \\
\text { emergency }\end{array}$ & $3.750^{*}$ & $0.790^{* *}$ & $32.66^{* *}$ & $0.292 \mathrm{~ns}$ & 0.75 & 6.80 \\
\hline Days to 50\% flowering & $4.310 \mathrm{~ns}$ & $1.541 \mathrm{~ns}$ & $294.0^{* *}$ & $0.875 \mathrm{~ns}$ & 3.81 & 4.30 \\
\hline
\end{tabular}

Where, ${ }^{*}$ and ${ }^{* *}$, significant at $\mathrm{p}<0.05$ and 0.01 , respectively, $\mathrm{ns}=$ non-significant, $\mathrm{Df}=$ degree of freedom and $\mathrm{CV}=$ Coefficient of variation.

\subsection{Mean of traits measured on plot basis}

The average marketable green pod yield, days to $50 \%$ emergency and days to $50 \%$ flowering for the two tested varieties in three locations are presented in Table 2. Comparing the three locations, the highest mean for character marketable green pod yield $(26.0 \mathrm{t} / \mathrm{ha})$ was observed from variety platie at Gumara kebele, Dera district, where as, the lowest green pod yield was recorded by variety BC-4.4 (8.5t/ha) at Libokemkem district (Angote kebele). In this study, it was generally observed that variety Platie performed higher than BC-4.4 in both locations with respect to marketable green pod yield. The results of this experiment further indicated that variety Platie matured earlier than BC-4.4. 
Table 1. Mean values of marketable green pod yield (t/ha), days to $50 \%$ emergency and $50 \%$ flowering.

\begin{tabular}{|c|c|c|c|c|c|c|c|c|c|c|c|c|}
\hline \multirow{2}{*}{ Varieties } & \multicolumn{4}{|c|}{ Marketable Green Pod Yield (t/ha) } & \multicolumn{4}{|c|}{ Days to $50 \%$ Emergency } & \multicolumn{4}{|c|}{ Days to $50 \%$ Flowering } \\
\hline & Fog & Libo & Gumara & Mean & Fog & Libo & Gumara & Mean & Fog & Libo & Gumara & Mean \\
\hline Platie & $22.8 \mathrm{a}$ & $10.2 \mathrm{a}$ & $26.0 \mathrm{a}$ & $19.7 \mathrm{a}$ & $12.0 \mathrm{a}$ & $12.3 \mathrm{a}$ & $11.8 \mathrm{a}$ & $12.0 \mathrm{a}$ & $42.5 \mathrm{a}$ & 42.3 & $41.5 \mathrm{a}$ & $42.1 \mathrm{a}$ \\
\hline BC-4.4 & $17.6 \mathrm{~b}$ & $8.5 \mathrm{a}$ & $22.3 \mathrm{a}$ & $16.1 \mathrm{~b}$ & $14.8 \mathrm{~b}$ & $14.3 \mathrm{a}$ & $13.8 \mathrm{a}$ & $14.3 \mathrm{~b}$ & $48.8 \mathrm{~b}$ & 49.8 & $49.0 \mathrm{~b}$ & $49.2 b$ \\
\hline GM & 20.2 & 9.40 & 24.2 & 17.9 & 13.4 & 13.3 & 12.8 & 13.1 & 45.6 & 46.0 & 45.3 & 45.6 \\
\hline $\mathrm{CV}$ & 8.30 & 18.5 & 10.8 & 11.5 & 5.06 & 2.94 & 10.1 & 7.80 & 5.30 & 2.94 & 3.00 & 3.89 \\
\hline $\mathrm{LSD}_{0.05}$ & 3.78 & 3.88 & 5.88 & 1.89 & 1.52 & 2.25 & 2.90 & 0.94 & 5.41 & 3.04 & 3.04 & 1.63 \\
\hline
\end{tabular}

N.B: Means with the same letter are not significantly different; GM= Grand Mean, CV=Coefficient of Variation, Libo= Libokemkem, Fog= Fogera

Moreover, the highest nonmarketable green pod yield $(12.9 \%)$ was produced by variety Platie at Libokemkem location. On the other hand, the lowest percentage nonmarketable green pod yield $(2.9 \%)$ was obtained at Gumara Kebele from variety Platie. In general, both varieties have shown higher percentage of nonmarketable green pod yield at Libokemkem presumably due to serious infestation by white fly insect during the field.

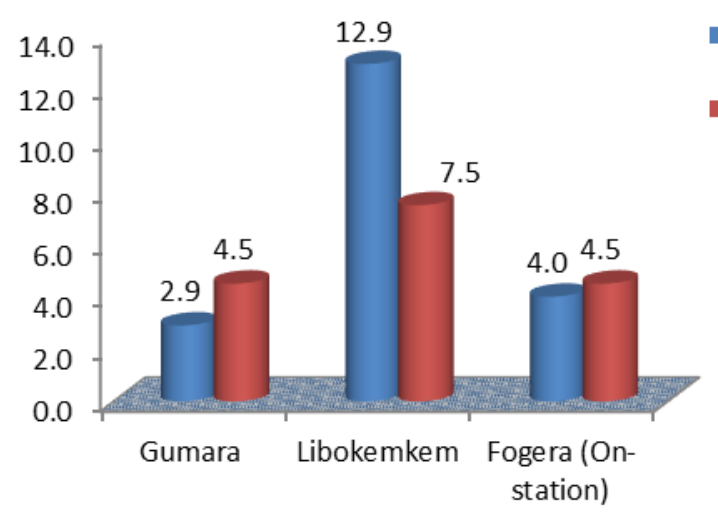

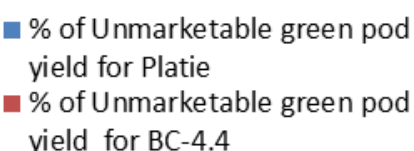

yield for BC-4.4

Figure 1. Percent of non-marketable green pod yield from total green pod yield across the three locations

\subsection{Mean of traits measured on individual plant basis}

The results in table 2 showed that significant differences were noted in plant height within varieties at Gumara and Libokemkem locations; whereas the varieties showed differences in number of primary branches at Fogera and in secondary branches at Libokemkem experimental sites. Maximum plant height $(57.1 \mathrm{~cm})$ and number of primary branches per plant (6) was recorded for variety BC-4.4, on the other hand variety Platie produced the highest number of secondary branches per plant (18).

Table 2. Mean values of plant height, number of primary and secondary branches for two varieties at three locations.

\begin{tabular}{|c|c|c|c|c|c|c|c|c|c|c|c|c|}
\hline \multirow{2}{*}{ Varieties } & \multicolumn{4}{|c|}{ Number of primary branches } & \multicolumn{4}{|c|}{ Number of secondary branches } & \multicolumn{4}{|c|}{ Plant height $(\mathrm{cm})$} \\
\hline & Fog & Libo & Gumara & Mean & Fog & Libo & Gumara & Mean & Fog & Libo & Gumara & Mean \\
\hline Platie & $4.4 \mathrm{a}$ & $4.6 \mathrm{a}$ & $4.8 \mathrm{a}$ & $4.7 \mathrm{a}$ & $11.3 \mathrm{a}$ & $17.8 \mathrm{a}$ & $17.6 \mathrm{a}$ & $15.5 \mathrm{a}$ & $48.3 \mathrm{a}$ & $49.9 \mathrm{a}$ & $50.8 \mathrm{a}$ & $49.7 \mathrm{a}$ \\
\hline BC-4.4 & $5.9 \mathrm{~b}$ & $4.9 \mathrm{a}$ & $5.0 \mathrm{a}$ & $5.3 \mathrm{a}$ & $13.7 \mathrm{a}$ & $16.3 \mathrm{~b}$ & $16.8 \mathrm{a}$ & $15.6 \mathrm{a}$ & $51.2 \mathrm{a}$ & $57.1 \mathrm{~b}$ & $55.0 \mathrm{~b}$ & $54.4 \mathrm{~b}$ \\
\hline GM & 5.10 & 4.80 & 4.90 & 5.00 & 12.5 & 17.0 & 17.2 & 15.5 & 49.7 & 53.5 & 52.9 & 52.0 \\
\hline $\mathrm{CV}$ & 17.9 & 13.6 & 12.3 & 14.5 & 12.1 & 28.9 & 5.50 & 19.4 & 7.90 & 4.50 & 3.30 & 5.5 \\
\hline $\mathrm{LSD}_{0.05}$ & 2.05 & 1.23 & 1.35 & 0.66 & 3.39 & 11.0 & 2.13 & 2.78 & 8.75 & 5.40 & 3.94 & 2.62 \\
\hline
\end{tabular}

N.B: Means with the same letter are not significantly different; GM= Grand Mean, CV= Coffiecient of Variation, Libo= Libokemkem, Fog=Fogera

At three locations, the study revealed significant differences in pod length between tested varieties; whereas pod width and pod weight showed non-significant difference with in these varieties at individual as well as 
across locations (table 3). Variety platie gave the highest mean pod length (14), width (8.4) and weight (6.8) over the three locations.

Table 3. Mean pod length, width and weight for two varieties at three locations.

\begin{tabular}{|c|c|c|c|c|c|c|c|c|c|c|c|c|}
\hline \multirow{2}{*}{ Varieties } & \multicolumn{4}{|c|}{ Pod Length $(\mathrm{cm})$} & \multicolumn{4}{|c|}{ Pod Width (mm) } & \multicolumn{4}{|c|}{ Pod Weight (gm.) } \\
\hline & Fog & Libo & Gumara & Mean & Fog & Libo & Gumara & Mean & Fog & Libo & Gumara & Mean \\
\hline Platie & $14.4 \mathrm{a}$ & $13.7 \mathrm{a}$ & $14.0 \mathrm{a}$ & $14.0 \mathrm{a}$ & $8.3 \mathrm{a}$ & $7.1 \mathrm{a}$ & $9.6 \mathrm{a}$ & $8.4 a$ & $6.7 \mathrm{a}$ & $5.9 \mathrm{a}$ & $8.4 \mathrm{a}$ & $6.8 \mathrm{a}$ \\
\hline BC-4.4 & $12.4 \mathrm{~b}$ & $12.1 \mathrm{~b}$ & $11.9 b$ & $12.1 \mathrm{~b}$ & $9.7 \mathrm{a}$ & $6.8 \mathrm{a}$ & $5.9 \mathrm{a}$ & $7.6 \mathrm{a}$ & $5.2 \mathrm{a}$ & $5.2 \mathrm{a}$ & $7.6 \mathrm{a}$ & $6.2 \mathrm{a}$ \\
\hline GM & 13.4 & 12.9 & 12.95 & 13.08 & 9.0 & 6.90 & 7.8 & 7.90 & 5.9 & 5.50 & 8.00 & 6.50 \\
\hline $\mathrm{CV}$ & 5.2 & 4.7 & 3.5 & 5.20 & 9.4 & 10.0 & 36.1 & 22.1 & 14.8 & 11.5 & 11.4 & 12.6 \\
\hline $\mathrm{LSD}_{0.05}$ & 1.57 & 1.36 & 1.31 & 1.03 & 1.88 & 1.54 & 6.34 & 1.61 & 1.97 & 1.42 & 2.05 & 0.75 \\
\hline
\end{tabular}

N.B: Means with the same letter are not significantly different; $G M=$ Grand Mean, $C V=$ Coefficient of Variation, Libo $=$ Libokemkem location, Fog $=$ Fogera location

\section{Conclusion and Recommendations}

In this study, variety platie produced higher mean marketable green pod yield, pod length, pod width, pod weight and less percentage of non-marketable green pod yields across locations. It has further exhibited earlier nature of maturity as compared to variety BC-4.4. Hence, platie is performed superior and recommended for production in South Gondar Zone especially in Fogera, Dera and Libokemkem districts. Therefore, seed multiplication and demonstration of this variety is a crucial to easily dissemination of seeds with its production practices into smallscale farmers in all testing locations and other areas that have related environmentally.

\section{Conflict of Interests}

The authors have not any conflict of interests

\section{Reference}

1. Alemu y, Ketema s, Hinsermu M, Geleto J, Tabor G, Aklilu S, Wendimu G, Binalfew T .2018. Performance of Snap Bean (Phaseolus vulgaris L.) Genotypes for Green Pod Yield and Quality in the Central Rift Valley of Ethiopia. Greener Journal of Plant Breeding and Crop Science, 6(1): 001-006

2. Negash A, Tulu S, Getachew E .2018. Yield and Yield Components of Snap Bean (Phaseolus vulgaris L.) as affected by N and Fertilizer Rates at Jimma, Southwestern Ethiopia. Adv Crop Sci Tech 6: 369.

3. PCARRD-DOST Portal. 2007. Snap beans: Industry Status

4. Wiersinga R, Jager A .2007. Identification of opportunities and setting agenda of activities in the Ethiopian fruits and vegetables sector. Mission Report, Ethiopian-Netherlands Horticulture Partnership. 